\title{
Acute Effect of Caffeine on the Synthesis of Pro-Inflammatory Cytokines in the Hypothalamus and Choroid Plexus during Endotoxin-Induced Inflammation in a Female Sheep Model
}

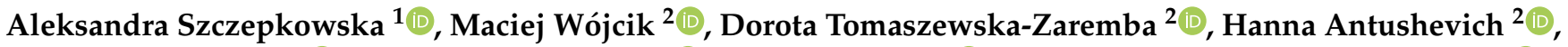 \\ Agata Krawczyńska $^{2}\left(\mathbb{0}\right.$, Wiktoria Wiechetek ${ }^{2,3}{ }^{-}$, Janina Skipor ${ }^{1, *(1)}$ and Andrzej Przemysław Herman $2, *(\mathbb{D})$ \\ 1 Institute of Animal Reproduction and Food Research, Polish Academy of Sciences, 10-748 Olsztyn, Poland; \\ a.szczepkowska@pan.olsztyn.pl \\ 2 The Kielanowski Institute of Animal Physiology and Nutrition, Polish Academy of Sciences, \\ 05-110 Jabłonna, Poland; m.wojcik@ifzz.pl (M.W.); d.tomaszewska@ifzz.pl (D.T.-Z.); \\ a.antuszewicz@ifzz.pl (H.A.); a.krawczynska@ifzz.pl (A.K.); w.wiechetek@ifzz.pl (W.W.) \\ 3 Department of Ichthyology and Biotechnology in Aquaculture, Institute of Animal Sciences, University of \\ Life Sciences, 02-786 Warsaw, Poland \\ * Correspondence: j.skipor@pan.olsztyn.pl (J.S.); a.herman@ifzz.pan.pl (A.P.H.)
}

Citation: Szczepkowska, A.; Wójcik, M.; Tomaszewska-Zaremba, D.; Antushevich, H.; Krawczyńska, A.; Wiechetek, W.; Skipor, J.; Herman, A.P. Acute Effect of Caffeine on the Synthesis of Pro-Inflammatory Cytokines in the Hypothalamus and Choroid Plexus during

Endotoxin-Induced Inflammation in a Female Sheep Model. Int. J. Mol. Sci. 2021, 22, 13237. https://doi.org/ 10.3390/ijms222413237

Academic Editor: Susana Merino Montero

Received: 17 November 2021

Accepted: 7 December 2021

Published: 8 December 2021

Publisher's Note: MDPI stays neutral with regard to jurisdictional claims in published maps and institutional affiliations.

Copyright: (c) 2021 by the authors. Licensee MDPI, Basel, Switzerland. This article is an open access article distributed under the terms and conditions of the Creative Commons Attribution (CC BY) license (https:// creativecommons.org/licenses/by/ $4.0 /)$.
Abstract: This study was designed to determine the effect of acute caffeine (CAF) administration, which exerts a broad spectrum of anti-inflammatory activity, on the synthesis of pro-inflammatory cytokines and their receptors in the hypothalamus and choroid plexus (ChP) during acute inflammation caused by the injection of bacterial endotoxin-lipopolysaccharide (LPS). The experiment was performed on 24 female sheep randomly divided into four groups: control; LPS treated (iv.; $400 \mathrm{ng} / \mathrm{kg}$ of body mass (bm.)); CAF treated (iv.; $30 \mathrm{mg} / \mathrm{kg}$ of bm.); and LPS and CAF treated. The animals were euthanized $3 \mathrm{~h}$ after the treatment. It was found that acute administration of CAF suppressed the synthesis of interleukin (IL-1 $\beta$ ) and tumor necrosis factor (TNF) $\alpha$, but did not influence IL-6, in the hypothalamus during LPS-induced inflammation. The injection of CAF reduced the LPS-induced expression of TNF mRNA in the ChP. CAF lowered the gene expression of IL-6 cytokine family signal transducer (IL6ST) and TNF receptor superfamily member 1A (TNFRSF1) in the hypothalamus and IL-1 type II receptor (IL1R2) in the ChP. Our study on the sheep model suggests that CAF may attenuate the inflammatory response at the hypothalamic level and partly influence the inflammatory signal generated by the $\mathrm{ChP}$ cells. This suggests the potential of CAF to suppress neuroinflammatory processes induced by peripheral immune/inflammatory challenges.

Keywords: brain; LPS; IL-1 $\beta$; IL-6; TNF $\alpha$; IL1R1; IL1R2; IL6R; IL6ST; TNFRSF1A; TNFRSF1B

\section{Introduction}

The inflammation caused by a bacterial or viral infection often influences the activity of neurons located in different hypothalamic nuclei that centrally regulate thermogenesis, food intake, reproduction, and circadian rhythms of rest-activity and sleep [1-4]. Bacterial endotoxins have been observed to disturb the mechanism regulating reproductive processes in cows [5], sheep [6], pigs [7], rats [8], and non-human primates [9]. Moreover, it has been found that inflammation induced by pathogenic bacteria may trigger premature uterine contractions causing pre-term delivery [10]. Actually, immune stress is thought to alter the reproductive process mainly at the level of the brain [11]. The pivotal role in the transmission of inflammatory signals from the periphery into the brain parenchyma play pro-inflammatory cytokines, particularly interleukin (IL)-1 $\beta$, IL-6, and tumor necrosis factor (TNF) $\alpha$, which concentration raises in the peripheral blood, cerebrospinal fluid (CSF) and brain parenchyma in response to lipopolysaccharide (LPS)-induced inflammation [12-15]. Studies on rats and sheep models indicated that both systemic LPS treatment and central administration of IL- $1 \beta$, and $\mathrm{TNF} \alpha$ into the region of the hypothalamus suppress the 
secretion of the gonadotropin-releasing hormone leading to downstream inhibition of the hypothalamic-pituitary-gonadal axis (HPG axis), the main neuroendocrine axis regulating reproduction [13,16-18]. On the other hand, pharmacological inhibition of the synthesis of pro-inflammatory cytokines in the hypothalamus during endotoxin-induced immune challenge has been shown to reduce the inhibitory effect of inflammation on the activity of the HPG axis in sheep during the follicular phase [19].

Although the area of the brain is protected against an uncontrolled influx of peripheral molecules by the blood-brain barrier (BBB) located in the endothelium of brain microvessels and by the blood-CSF-barrier (BCSFB) in the epithelium of the choroid plexus (ChP), IL$1 \beta, \mathrm{TNF} \alpha$, and IL- 6 cross brain barriers through saturable transport mechanisms [20,21]. Moreover, pro-inflammatory cytokines are also synthesized in the $\mathrm{ChP}$, brain microvessels, and parenchyma in response to peripheral LPS administration [22-24]. The ChP serves as a place for elaboration of signal molecules that communicate peripheral immune status to the brain, and as a gateway for immune cells trafficking into the CSF $[25,26]$.

The growing evidence suggests that caffeine (CAF), a plant alkaloid structurally related to adenosine, has an anti-inflammatory action [27-29]. Long-term CAF administration decreases the expression of IL-1 $\beta$, IL- 6 , and TNF- $\alpha$ in monocytes and macrophages, indicating the possibility of a chronic decrease of local inflammation [30,31]. The ability of $\mathrm{CAF}$ to attenuate pro-inflammatory cytokines expression may result from the fact that it binds with adenosine receptors (ADORs), which belong to the P1 family of purinergic $G$ protein-coupled receptors including $A 1, A 2 A, A 2 B$, and $A 3$ receptors [32]. CAF demonstrates the highest affinity for $\mathrm{A} 1$ and $\mathrm{A} 2 \mathrm{~A}$, and the lowest affinity for $\mathrm{A} 2 \mathrm{~B}$ and A3 [33]. The expression of ADORs has been demonstrated in the brain [34], including ChP in rodents [35,36], pig [35], and human [37,38].

Therefore, based on the assumptions that CAF receptors are widespread in the brain, and CAF may influence pro-inflammatory cytokines synthesis in the immune cells, we hypothesized that CAF decreases the immune response to LPS-induced acute inflammation in the hypothalamus and ChP. With the use of the female sheep model, which exhibits similar sensitivity to LPS [39] and has a diurnal activity pattern as humans [40], we evaluated the effect of acute administration of CAF on the expression of pro-inflammatory cytokines (IL-1 $\beta$, IL-6, and TNF- $\alpha$ ) and their receptors (IL-1 receptor type I-IL1R1 and type II-IL1R2, IL-6 receptor-IL6R and signal-transducing component-IL6ST, TNF $\alpha$ receptor type I-TNFRSF1A and type II-TNFRSF1B) in the hypothalamus and ChP during an immune/inflammatory challenge induced in the follicular phase of the estrous cycle.

\section{Results}

2.1. The Effect of Caffeine on Gene Expression and Concentration of Pro-Inflammatory Cytokines in the Hypothalamus under Basal and LPS-Challenge Conditions

All LPS-treated female sheep responded with a significant increase $(p<0.05)$ of body temperature and blood plasma cortisol concentration (Supplementary Figure S1). At the hypothalamus level, the single injection of LPS affected $(p<0.05)$ the expression of all examined pro-inflammatory cytokines: IL- $1 \beta$, IL- 6 , and $\mathrm{TNF} \alpha$, as indicated by higher $(p<0.05)$ mRNA expression together with an increase $(p<0.05)$ of cytokines concentration in the LPS/C group compared to the control (Figure 1A-C with inserts). In turn, the single injection of CAF had no effect on IL-1 $\beta$ expression on both mRNA and protein levels (Figure 1A with insert), as well as on IL6 mRNA expression (Figure 1B insert) and $\mathrm{TNF} \alpha$ protein level (Figure 1C), but increased $(p<0.05)$ the protein level of IL-6, and decreased $(p<0.05)$ the mRNA expression of TNF in the CAF/C group compared to the control (Figure 1B,C insert, respectively). The combined LPS and CAF treatment affected $(p<0.05)$ expression of IL-1 $\beta$ and TNF $\alpha$ on both mRNA and protein levels, which were lower $(p<0.05)$ in the LPS/CAF than in the LPS/C group (Figure 1A,C with inserts), but it did not change IL-6 on both mRNA and protein levels (Figure 1B with insert). 
A

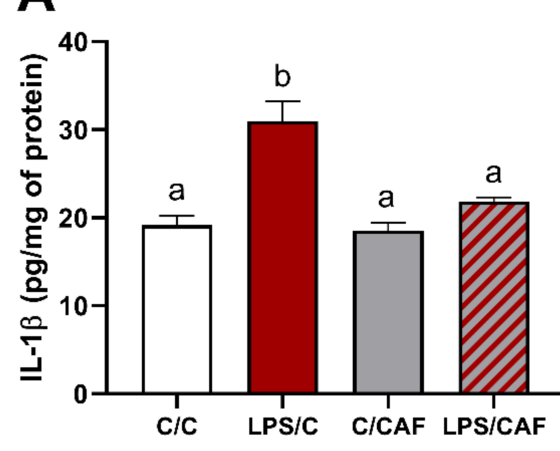

B
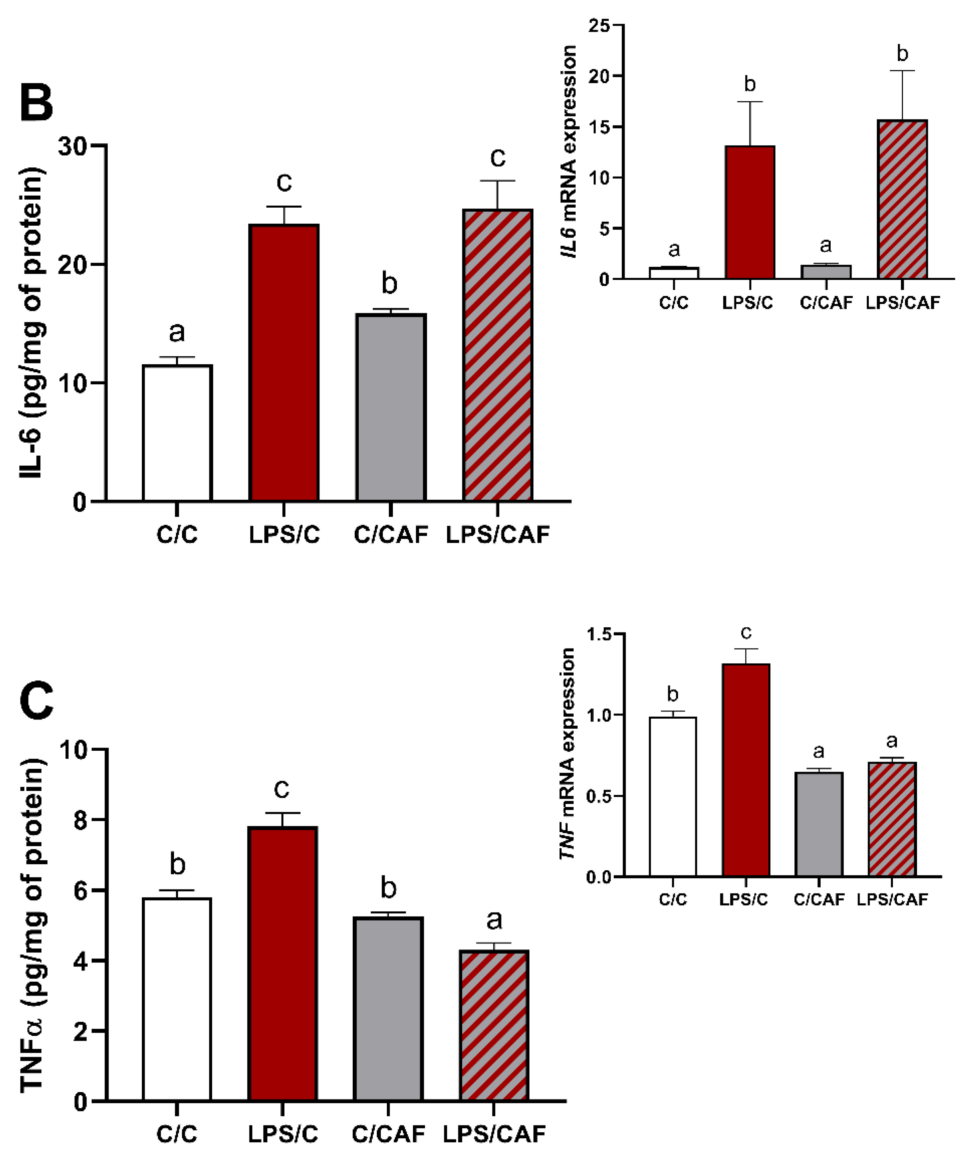
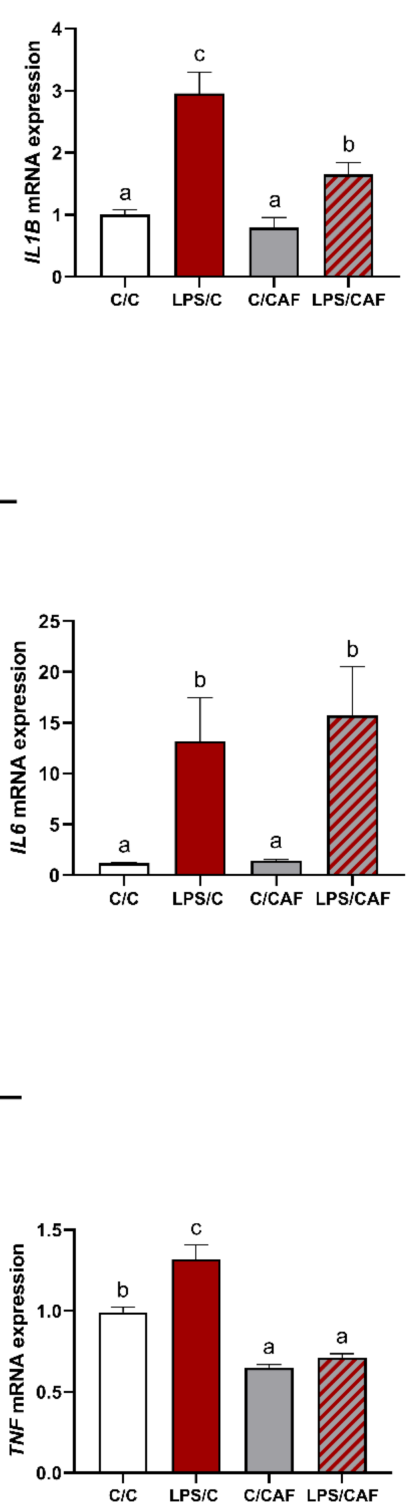

Figure 1. Mean ( \pm SEM) concentration and gene expression (insert) of pro-inflammatory cytokines: interleukin 1beta (A), interleukin 6 (B) and tumor necrosis factor-alpha (C) in the ovine hypothalamus in saline- (C/C, $0.9 \% \mathrm{NaCl}$ iv., white bars), lipopolysaccharide- (LPS/C, $400 \mathrm{ng} / \mathrm{kg}$ of body mass (bm.), iv., red bars), caffeine- (C/CAF, $30 \mathrm{mg} / \mathrm{kg}$ of bm., iv., grey bars) and LPS/CAF- (red-grey hatched bars) treated female sheep. Different letters indicate significant differences at $p<0.05$, according to one-way ANOVA followed by Fisher's post hoc test comparing groups with each other.

2.2. The Effect of Caffeine on Pro-Inflammatory Cytokines Receptors Gene Expression in the Ovine Hypothalamus under Basal and LPS-Challenge Conditions

The LPS injection significantly increased $(p<0.05)$ all pro-inflammatory cytokines receptors, except $I L 6 R$, in the hypothalamus, as indicated by their higher $(p<0.05)$ gene expression in the LPS/C group than in the control (Table 1). The single injection of CAF alone affected only IL6ST, which gene expression was higher $(p<0.05)$ in C/CAF than in the control group. In turn, CAF used together with LPS attenuated LPS action on IL6ST 
and TNFRSF1A, as indicated by their lower $(p<0.05)$ gene expression in LPS/CAF than in the LPS/C group.

Table 1. The effect of caffeine on the relative gene expression (mean \pm SEM; $n=6$ ) of pro-inflammatory cytokines receptors in the ovine hypothalamus in basal and lipopolysaccharide-challenge conditions.

\begin{tabular}{|c|c|c|c|c|}
\hline Gene & $\mathrm{C} / \mathrm{C}$ & LPS/C & C/CAF & LPS/CAF \\
\hline $\begin{array}{c}\text { IL1R1 } \\
\text { interleukin } 1 \text { receptor } 1\end{array}$ & $1 \pm 0.1^{\mathrm{A}}$ & $2.8 \pm 0.4^{B}$ & $1.3 \pm 0.1^{\mathrm{A}}$ & $2.3 \pm 0.3^{B}$ \\
\hline $\begin{array}{l}\text { IL1R2 } \\
\text { interleukin } 1 \text { receptor } 2\end{array}$ & $1 \pm 0.1^{\mathrm{A}}$ & $4.5 \pm 0.7^{\mathrm{B}}$ & $1.5 \pm 0.1^{\mathrm{A}}$ & $4.2 \pm 0.6^{\mathrm{B}}$ \\
\hline $\begin{array}{c}\text { IL6R } \\
\text { interleukin } 6 \text { receptor }\end{array}$ & $1 \pm 0.1^{\mathrm{A}}$ & $1 \pm 0.1^{\mathrm{A}}$ & $1.1 \pm 0.1^{\mathrm{A}}$ & $1 \pm 0.1^{\mathrm{A}}$ \\
\hline $\begin{array}{c}\text { IL6ST } \\
\text { interleukin } 6 \text { signal transducer }\end{array}$ & $1 \pm 0.1^{\mathrm{A}}$ & $1.4 \pm 0.1^{C}$ & $1.2 \pm 0.1^{\mathrm{B}}$ & $1.3 \pm 0.1^{\mathrm{B}}$ \\
\hline $\begin{array}{c}\text { TNFRSF1A } \\
\text { TNF receptor superfamily member 1A }\end{array}$ & $1 \pm 0.1^{\mathrm{A}}$ & $1.6 \pm 0.2^{\mathrm{B}}$ & $0.8 \pm 0.1^{\mathrm{A}}$ & $1 \pm 0.1^{\mathrm{A}}$ \\
\hline $\begin{array}{c}\text { TNFRSF1B } \\
\text { TNF receptor superfamily member 1B }\end{array}$ & $1 \pm 0.1^{\mathrm{A}}$ & $1.9 \pm 0.3^{\mathrm{B}}$ & $1.1 \pm 0.1^{\mathrm{A}}$ & $1.8 \pm 0.1^{\mathrm{B}}$ \\
\hline
\end{tabular}

C/C—-double treated with saline $(0.9 \% \mathrm{NaCl}$ iv.), LPS/C—treated with lipopolysaccharide (LPS, $400 \mathrm{ng} / \mathrm{kg}$ of bm., iv.) followed by saline, $\mathrm{C} / \mathrm{CAF}$-treated with saline followed by caffeine (CAF, $30 \mathrm{mg} / \mathrm{kg}$ of body mass (bm.), iv.), LPS/CAF-treated with LPS followed by CAF. Gene expression data were normalized to the average relative level of this mRNA expression in the control sheep (C/C), which was set to 1.0. Different letters indicate significant differences at $p<0.05$, according to one-way ANOVA followed by Fisher's post hoc test comparing groups with each other.

\subsection{The Effect of Caffeine on Gene Expression of Pro-Inflammatory Cytokines and Their Receptors in the Choroid Plexus under Basal and LPS-Challenge Conditions}

As indicated in Table 2, mRNA expression of pro-inflammatory cytokines and their corresponding receptors, except ILR6 and TNF in the ovine ChP, was significantly higher $(p<0.05)$ in the LPS/C group than in the control. The single injection of CAF alone increased $(p<0.05)$ only IL6 and IL6ST gene expressions. In turn, CAF used together with LPS attenuated LPS action on IL1R2 and TNF, as indicated by their lower $(p<0.05)$ gene expression in the LPS/CAF than in the LPS/C group.

Table 2. The effect of caffeine on the relative gene expression (mean $\pm \mathrm{SEM} ; n=6$ ) of pro-inflammatory cytokines and their receptors in the ovine choroid plexus in basal and lipopolysaccharide-challenge conditions.

\begin{tabular}{|c|c|c|c|c|}
\hline Gene & $\mathrm{C} / \mathrm{C}$ & LPS/C & C/CAF & LPS/CAF \\
\hline $\begin{array}{c}\text { IL1B } \\
\text { interleukin } 1 \beta ; \text { IL1R1 }\end{array}$ & $1 \pm 0.1^{\mathrm{A}}$ & $7.8 \pm 2.1^{B}$ & $0.7 \pm 0.1^{\mathrm{A}}$ & $9.8 \pm 3.1^{B}$ \\
\hline $\begin{array}{c}\text { IL1R1 } \\
\text { interleukin } 1 \text { receptor } 1\end{array}$ & $1 \pm 0.1^{\mathrm{A}}$ & $3.6 \pm 0.8^{\mathrm{B}}$ & $2.3 \pm 0.3^{\mathrm{A}}$ & $4.1 \pm 0.4^{\mathrm{B}}$ \\
\hline $\begin{array}{c}\text { IL1R2 } \\
\text { interleukin } 1 \text { receptor } 2\end{array}$ & $1 \pm 0.2^{\mathrm{A}}$ & $9.7 \pm 1.6^{\mathrm{C}}$ & $2.1 \pm 0.3^{\mathrm{A}}$ & $6.5 \pm 0.3^{B}$ \\
\hline $\begin{array}{l}\text { IL-6 } \\
\text { interleukin } 6\end{array}$ & $1 \pm 0.1^{\mathrm{A}}$ & $587.4 \pm 146.0^{\mathrm{C}}$ & $1.9 \pm 0.2^{\mathrm{B}}$ & $489.7 \pm 58.0^{C}$ \\
\hline $\begin{array}{c}I L 6 R \\
\text { interleukin } 6 \text { receptor }\end{array}$ & $1 \pm 0.1^{\mathrm{AB}}$ & $0.8 \pm 0.2^{\mathrm{A}}$ & $1.4 \pm 0.2^{\mathrm{B}}$ & $0.8 \pm 0.1^{\mathrm{A}}$ \\
\hline $\begin{array}{c}\text { IL6ST } \\
\text { interleukin } 6 \text { signal transducer }\end{array}$ & $1 \pm 0.1^{\mathrm{A}}$ & $2.8 \pm 0.4^{\mathrm{C}}$ & $1.9 \pm 0.2^{\mathrm{B}}$ & $2.9 \pm 0.2^{C}$ \\
\hline $\begin{array}{c}T N F \\
\text { tumor necrosis factor }\end{array}$ & $1 \pm 0.1^{\mathrm{AB}}$ & $2.1 \pm 0.8^{\mathrm{B}}$ & $0.7 \pm 0.1^{\mathrm{A}}$ & $0.8 \pm 0.2^{\mathrm{A}}$ \\
\hline $\begin{array}{c}\text { TNFRSF1A } \\
\text { TNF receptor superfamily member 1A }\end{array}$ & $1 \pm 0.1^{\mathrm{A}}$ & $1.5 \pm 0.2^{\mathrm{B}}$ & $1.1 \pm 0.1^{\mathrm{A}}$ & $1.4 \pm 0.1^{\mathrm{B}}$ \\
\hline $\begin{array}{c}\text { TNFRSF1B } \\
\text { TNF receptor superfamily member 1B }\end{array}$ & $1 \pm 0.1^{\mathrm{A}}$ & $3.8 \pm 0.8^{\mathrm{B}}$ & $1.7 \pm 0.3^{\mathrm{A}}$ & $4.0 \pm 0.3^{\mathrm{B}}$ \\
\hline
\end{tabular}

C/C-double treated with saline $(0.9 \% \mathrm{NaCl}$ iv.), LPS/C-treated with lipopolysaccharide (LPS, $400 \mathrm{ng} / \mathrm{kg}$ of bm., iv.) followed by saline, $\mathrm{C} / \mathrm{CAF}$-treated with saline followed by caffeine (CAF, $30 \mathrm{mg} / \mathrm{kg}$ of body mass (bm.), iv.), LPS/CAF-treated with LPS followed by CAF. Gene expression data were normalized to the average relative level of this mRNA expression in the control sheep $(\mathrm{C} / \mathrm{C})$, which was set to 1.0. Different letters indicate significant differences at $p<0.05$, according to one-way ANOVA followed by Fisher's post hoc test comparing groups with each other. 


\section{Discussion}

Our study has shown that CAF influences the synthesis of pro-inflammatory cytokines in the brain during the immune/inflammatory challenge induced by bacterial endotoxin injection in sheep during the follicular phase. As indicated previously [41], acute LPS treatment did not affect blood plasma progesterone and estradiol concentrations in the used female sheep model. It was found that the single injection of CAF in a dose of $30 \mathrm{mg} / \mathrm{kg}$ of bm. decreased mRNA expression of IL1B in the hypothalamus in LPS-treated female sheep, however, the reduced level of IL1B gene expression remained higher than in control animals. On the other hand, the administration of CAF completely abolished the endotoxin-stimulating effect on the level of IL- $1 \beta$ protein. Obtained results are in line with the recent study of Mallik et al. [42] where 14 days of CAF-treatment reduced LPS-stimulated IL-1 $\beta$ synthesis in the brain of male mice. Our results clearly indicate that the effect of CAF on the synthesis of IL-1 $\beta$ is not only connected with inhibiting IL1B gene expression but also influences the post-transcriptional stages. In general, LPS action in the brain is limited by BBB and most effects of peripherally administered LPS on the brain are therefore mediated by LPS receptors located outside the brain [43]. The LPS receptor, the toll-like receptor 4 (TLR4) is expressed in the endothelium of brain microvessels and the ChP $[44,45]$. In the case of IL-1 $\beta$, LPS binding to TLR4 induces the synthesis of an inactive precursor, termed pro-IL-1 $\beta$, which needs to be cleaved by caspase- 1 to become an active molecule [46]. The activation of caspase- 1 occurs via its recruitment to a multi-protein complex termed the inflammasome, which is composed of an adaptor molecule, a cytosolic pattern recognition receptor (NLRP3), and pro-caspase-1 [46]. It is evidenced that NLRP3 inflammasome expression in microglia, astrocytes, and brain microvessels endothelial cells which activation may create conditions necessary for active IL- $1 \beta$ synthesis [47-49]. The in vivo study on C57BL/ 6 mice reported that CAF may reduce NLRP3 inflammasome activation via the induction of autophagy in microglial cells [50]. Considering this, similar action of CAF on NLRP3 inflammasome in the ovine hypothalamus (including also brain microvessels) may be expected. In the ChP, no effect of CAF on LPS-induced IL1B expression was observed. This may be connected to the high cellular heterogeneity of $\mathrm{ChP}$ composed of the epithelial, endothelial, and stromal immune system cells, mainly bone marrow-derived macrophages (BMDMs) and dendritic cells [25]. It is worth mentioning that the immunomodulatory effect of CAF could be dependent upon the kind of target cells. According to Shimada and Hasegava-Ishii [51] ChP macrophages are cells that produce IL-1 $\beta$ in response to LPS stimulation, while other ChP cells rarely express IL- $1 \beta$ in early response to systemic LPS. During inflammatory conditions macrophages are stimulated and can be differentiated/polarized into classically activated (M1) macrophages, characterized by their ability to guide acute inflammatory responses and alternatively activated (M2) macrophages, which have inflammation resolving activity [52]. It is not known which subset of macrophages dominates in the ovine ChP during LPS-induced acute inflammation. Just recently, Ivan et al. [53] demonstrated that the BCSFB at the ChP could constitute a central nervous system (CNS) access gateway and a priming site for both M1 and M2 macrophages.

According to Kovács et al. [54], CAF enhanced the expression of IL-1 $\beta$, in the subset of human M2 macrophages, whereas it did not influence the expression of IL1- $\beta$ in the subset of M1 macrophages and mouse BMDM. Moreover, the same study [54] also showed that there were important differences in the time of cell response to CAF action. In M2 macrophages CAF enhanced IL- $1 \beta$ secretion as early as $6 \mathrm{~h}$ after LPS administration, while in monocytes only after $12 \mathrm{~h}$ [54]. Therefore, the differences in the response of the hypothalamus and $\mathrm{ChP}$ to $\mathrm{CAF}$ may be due to the different cellular compositions, locations, and nature of these structures. Considering IL-1 $\beta$ receptors, CAF attenuated LPS-induced IL1R2 and has no effect on IL1R1 gene expressions in the ovine ChP and both receptors in the hypothalamus. This is new and important information which, in light of the reports on the potential role of the IL-1 type II receptor (coded by IL1R2 gene) in the transport of IL-1 $\beta$ throughout brain barriers [55], as well as the demonstration that activation of A1 and 
A2A receptors facilitates the entry of macromolecules throughout the BBB in mice [56], and the fact that antagonism of AR signaling blocks the entry of inflammatory cells and soluble factors into the brain [57], requires further research. Unfortunately, the main limitation of our study was the lack of antibodies suitable to detect this receptor in the ovine tissue.

In the LPS-challenge condition, a single injection of CAF abolished TNF $\alpha$ synthesis in the ovine hypothalamus which was observed at both mRNA and protein levels. Our results are consistent with a previous in vivo study on the LPS-injected mouse model, which showed that CAF attenuated the endotoxin-induced release of TNF $\alpha$ in the mouse brain [42]. According to our results, CAF down-regulated LPS-induced TNF expression also in the ovine ChP. Interestingly, opposite to IL- $1 \beta$ secretion, CAF abolished TNF $\alpha$ synthesis in both M1 and M2 macrophages as well as in monocytes [54]. Likewise, the in vitro study on LPS-stimulated human whole blood demonstrated that concentrations of CAF relevant to human consumption consistently decreased TNF $\alpha$ concentration in blood and that this effect was mediated by the cAMP/protein kinase A pathway [58]. Considering TNF $\alpha$ receptors, CAF attenuated only LPS-induced TNFRSF1A gene expression in the hypothalamus. It has been demonstrated that binding of TNF $\alpha$ to TNFR-1 (coded by TNFRSF1A gene) is sufficient to attain TNF $\alpha$ mediated cell killing while binding to TNFR-2 (coded by TNFRSF1B) is not [59].

Despite an in vitro study on RAW264.7 cells suggesting that CAF may have an inhibitory effect on IL-6 production under inflammatory conditions [60], and an in vivo study reporting the suppressory effect of CAF administration on IL-6 synthesis in mice brains [42], our study did not find an effect of acute CAF administration on the synthesis of IL-6 in the hypothalamus and IL6 gene expression in the ChP of endotoxin-treated female sheep. We also did not observe CAF action on IL-6 receptors, IL6R, and IL6ST gene expression in both structures, except for weak attenuation of LPS-action on IL6ST in the hypothalamus. Our observations also show that the effect of CAF action on the synthesis of the pro-inflammatory cytokines in these structures seems to be dependent on animal health status and cytokines themselves. In healthy female sheep, CAF stimulated mostly IL-6 synthesis and gene expression of its signal-transducing component (IL6ST) in the hypothalamus and IL6 and IL6ST gene expression in the ChP. The ability of CAF to modulate IL-6 synthesis in healthy subjects has been previously reported, however, the manner of this interaction is not clearly established. The studies on athletes showed that CAF supplementation increased the blood concentration of IL-6 in the response to exercise $[61,62]$. CAF action on IL-6 synthesis may be also dependent upon the target tissue or cell since in mice CAF was demonstrated to induce IL-6 synthesis by skeletal muscles and cultured myotubes but not by the liver, hepatocytes, adipocytes, and macrophages [63]. Determining the importance of the effects of CAF on the synthesis of IL- 6 in the hypothalamus for the functioning of the central nervous system certainly requires further in-depth research, because this cytokine has been found to play both neurotoxic and neuroprotective roles in the brain [64]. Our study demonstrated that CAF administrated alone also reduced TNF gene expression but only in the hypothalamus.

Determining the exact mechanism by which CAF influences the expression of proinflammatory cytokines in the brain is difficult due to limited data concerning this issue. It seems that the anti-inflammatory effect of CAF on the production of cytokines is the result of a multidirectional effect. Previous studies showed that ADORs such as A2A, A2B, and $\mathrm{A} 3$ are involved in the regulation of the release of pro-inflammatory mediators such as TNF- $\alpha$, IL-6, IL-12, nitric oxide, and macrophage inflammatory protein (MIP)- $1 \alpha$, and stimulated IL-10 secretion [65]. Particularly A3 receptor agonist was found to inhibit the synthesis of pro-inflammatory cytokines via down-regulation of NF- $\mathrm{kB}$, a transcription factor that induces the production of a panel of pro-inflammatory cytokines including TNF$\alpha$, IL-1, and IL-6 [65]. However, the other study on LPS-activated cord blood monocytes suggested that A1, but not A3, acts as an operative in the effect of CAF on TNF- $\alpha$ [33]. Other research on University of Chile Bibulous rats showed that acting through the A1 and A2A $\mathrm{CAF}$ plays a neuroprotective role and may attenuate ethanol-induced inflammation in the 
cerebellum [66]. One of the endogenous mechanisms involved in the regulation of immune response and cytokine secretion is the cholinergic anti-inflammatory pathway in which the efferent vagus nerve regulates systemic cytokine levels through $\alpha 7$ nicotinic acetylcholine (ACh) receptor [67]. Our previous studies with different inhibitors of acetylcholinesterase (AChE), an enzyme responsible for ACh hydrolysis, showed suppression of IL-1 $\beta$, IL-6, and TNF $\alpha$ synthesis in the ovine hypothalamus but not in the ChP which is linked with the lack of $\alpha 7$ nicotinic ACh receptor [68]. Considering the fact that CAF was demonstrated to act also as a non-competitive AChE inhibitor [69], a similar mechanism can be suggested for CAF action in the ovine hypothalamus.

\section{Materials and Methods}

\subsection{Animals and Experimental Design}

The experiment was performed on 2-years old Blackhead female sheep $(n=24)$ in the follicular phase of the estrous cycle during the breeding season (October). To standardize experimental conditions the stages of the estrous cycle were synchronized by the Chronogest ${ }^{\circledR}$ CR (Merck Animal Health, Madison, NJ, USA) method. The experimental procedures were performed $24 \mathrm{~h}$ following PMSG injection. On the morning of the experiment, animals were placed in individual cages and randomly divided into four experimental groups (Table 3) receiving intravenously the following treatment: (1) control group $(\mathrm{C} / \mathrm{C})$ - double saline $(0.9 \% w / v \mathrm{NaCl})$, (2) LPS group (LPS/C)—LPS (Escherichia coli 055:B5, Sigma Aldrich, Merck, Darmstadt, Germany) in a dose of $400 \mathrm{ng} / \mathrm{kg} \mathrm{bm}$. to induce immune stress and then saline, (3) CAF group (C/CAF)—saline and then CAF (Sigma Aldrich, Merck, Darmstadt, Germany) in a dose of $30 \mathrm{mg} / \mathrm{kg}$ bm. chosen based on [70] and the pilot experiment (Supplementary Figure S2), (4) LPS + CAF group (LPS/CAF)—LPS, and then CAF. During the experiment, the body temperature was measured and blood samples were collected through a catheter inserted into the jugular vein. The animals were sacrificed $3 \mathrm{~h}$ after treatment and after decapitation, the brains were rapidly dissected from the skulls. The ChP were removed from their anchoring to the Galien's vein, and the split was made along the mid-line, separating the $\mathrm{ChP}$ from each lateral ventricle. The hypothalamus and $\mathrm{ChP}$ were immediately frozen in liquid nitrogen and stored at $-80{ }^{\circ} \mathrm{C}$ until use.

Table 3. Experiment organization chart.

\begin{tabular}{cccccc}
\hline Group & $\begin{array}{c}\text { No. of } \\
\text { Animals }\end{array}$ & $\begin{array}{c}\text { Experimental } \\
\text { Treatment I }\end{array}$ & Dose [ng/kg] & $\begin{array}{c}\text { Experimental } \\
\text { Treatment II }\end{array}$ & $\begin{array}{c}\text { Dose } \\
\text { [mg/kg] }\end{array}$ \\
\hline C/C & 6 & $\mathrm{NaCl}$ & 0 & $\mathrm{NaCl}$ & 0 \\
LPS/C & 6 & $\mathrm{LPS}$ & 400 & $\mathrm{NaCl}$ & 0 \\
C/CAF & 6 & $\mathrm{NaCl}$ & 0 & caffeine & 30 \\
LPS/CAF & 6 & LPS & 400 & caffeine & 30 \\
\hline
\end{tabular}

C/C-saline-treated, control; LPS/C-lipopolysaccharide-treated; C/CAF-caffeine-treated; LPS/CAFlipopolysaccharide- and caffeine-treated.

\subsection{Inflammatory Cytokines and Cortisol Concentration Assessment}

The concentrations of pro-inflammatory cytokines in the hypothalamus were assayed using IL-1 $\beta$ ELISA kits (cat no. ESH0012; Wuhan Fine Biotech Co., Ltd., Wuhan, China), IL-6 ELISA kits (cat no. ESH0019; Wuhan Fine Biotech Co., Ltd., Wuhan, China) TNF $\alpha$ ELISA kits (cat no. ESH0025; Wuhan Fine Biotech Co., Ltd., Wuhan, China) designed and validated for sheep. The hypothalamic tissues were homogenized according to the method described elsewhere [68]. The assays procedures were performed according to the instructions provided by the manufacturer. Plates incubation and absorbance measurement at a wavelength of $450 \mathrm{~nm}$ were performed using the VersaMax reader (Molecular Devices LLC., Sunnyvale, CA, USA). The assay sensitivity was $18.75 \mathrm{pg} / \mathrm{mL}$ for IL- $1 \beta, 4.69 \mathrm{pg} / \mathrm{mL}$ for IL-6, and $9.375 \mathrm{pg} / \mathrm{mL}$ for TNF $\alpha$. The concentration of pro-inflammatory cytokines in the hypothalamus was calculated relative to the total protein content of the sample assayed 
by the Bradford method. The mean concentration of total protein per well in the ELISA assays was $2.4 \pm 0.1 \mathrm{mg} / \mathrm{mL}$.

To validate the ewe's responses to LPS administration, the plasma concentration of cortisol was assayed by RIA [71]. The sensitivity of the assay for cortisol was $0.95 \mathrm{ng} / \mathrm{mL}$, and the intra- and inter-assay coefficients of variation were $10 \%$ and $12 \%$, respectively.

\subsection{Relative Gene Expression Determination}

Relative gene expression assays were performed according to the previously published methods for hypothalamic [68] and the choroid plexus samples [72]. Frozen hypothalamic samples were homogenized by trituration in liquid nitrogen and lysed in lysing buffer (RA1) from the NucleoSpin ${ }^{\circledR}$ RNA kit (MACHEREY-NAGEL GmbH and Co, Düren, Germany). Frozen ChP samples were homogenized using a FastPrep24 instrument (MP Biomedicals, Illkirch-Graffenstaden, France) and dedicated to Lysing Matrix D tubes (MP Biomedicals, Illkirch-Graffenstaden, France), filled with lysing buffer (RA1). Total RNA isolation from the hypothalamic and ChP samples was carried out using the NucleoSpin ${ }^{\circledR}$ RNA kit (MACHEREY-NAGEL GmbH and Co, Düren, Germany), according to the manufacturer protocol. The concentration and purity of isolated RNA were quantified by measuring the optical density at 230,260, and $280 \mathrm{~nm}$ in a NanoDrop 1000 apparatus (Thermo Fisher Scientific Inc., Waltham, MA, USA). The verification of RNA integrity was carried out by electrophoresis using $1.2 \%$ agarose gel containing the GelRed Nucleic Acid Gel Stain (Biotium, Fremont, CA, USA). cDNA synthesis was performed using 1000 ng of total RNA and components of the Maxima ${ }^{\mathrm{TM}}$ First Strand cDNA Synthesis Kit for RT-qPCR (Thermo Fisher Scientific Inc., Waltham, MA, USA).

Real-Time RT-PCR analysis was carried out with the use of the HOT FIREPol EvaGreen ${ }^{\circledR}$ qPCR Mix Plus (Solis BioDyne, Tartu, Estonia) for the hypothalamic samples and the DyNAmo SYBR Green qPCR kit with ROX (Thermo Fisher Scientific, Waltham, MA, USA) for the ChP samples, and HPLC-grade oligonucleotide primers (Genomed, Warszawa, Poland) in line with the method described elsewhere [68,72]. Specific primers to determine the expression of the tested and reference genes were chosen based on our previous experience (see Table 4). For hypothalamic samples, one reaction mixture of total volume amounting to $15 \mu \mathrm{L}$ contained: $3 \mu \mathrm{L}$ of PCR Master Mix, $10.05 \mu \mathrm{L}$ of RNase-free water, $0.45 \mu \mathrm{L}$ of primers $(0.225 \mu \mathrm{L}$ each primer) and $1.5 \mu \mathrm{L}$ of the cDNA template. The real-time PCR reactions were carried out using a Rotor-Gene 6000 instrument (Qiagen, Dusseldorf, Germany) with the following protocol: $95{ }^{\circ} \mathrm{C}$ for $15 \mathrm{~min}$ and $30-35$ cycles at $95{ }^{\circ} \mathrm{C}$ for $10 \mathrm{~s}$ (denaturation), $59^{\circ} \mathrm{C}$ for $20 \mathrm{~s}$ (primer annealing) and $72{ }^{\circ} \mathrm{C}$ for $10 \mathrm{~s}$ (extension). The relative gene expression was calculated using the comparative quantification option [73] of a Rotor Gene 6000 software 1.7. (Qiagen, Dusseldorf, Germany) with reference to the mean expression of three housekeeping genes: glyceralde-hyde-3-phosphate dehydrogenase $(G A P D H), \beta$-actin $(A C T B)$, and histone deacetylase1 (HDAC1). For ChP samples, each reaction mixture of total volume amounting to $10 \mu \mathrm{L}$ contained: $5 \mu \mathrm{L}$ of DyNAmo SYBR Green qPCR kit with ROX (Thermo Fisher Scientific, Waltham, MA, USA), $0.2 \mu \mathrm{M}$ of each primer, and $3 \mu \mathrm{L}$ cDNA template (1:10). The real-time PCR reactions were carried out using a Viia7 instrument (Applied Biosystems by Life Technologies, Waltham, MA, USA) and cDNA samples and reaction mix were transferred into 384-well plates, by the Bravo Automated Liquid Handling Platform (Agilent Technologies, Santa Clara, CA, USA) and the following protocol was used: $95^{\circ} \mathrm{C}$ for $10 \mathrm{~min}$ and $37-40$ cycles at $95^{\circ} \mathrm{C}$ for $15 \mathrm{~s}$ (denaturation), $60^{\circ} \mathrm{C}$ for $30 \mathrm{~s}$ (primer annealing) and $72{ }^{\circ} \mathrm{C}$ for $30 \mathrm{~s}$ (extension). The relative gene expression was calculated using the Real-Time PCR Miner (available online: http: / / ewindup.info/miner/, accessed on 27 March 2021) based on the Zhao and Fernald [74] algorithm, with reference to the mean expression of three housekeeping genes: $G A P D H, A C T B$, and $H D A C 1$. A final melting curve analysis and agarose gel electrophoresis of PCR products were performed to verify the specificity of the amplification reaction after real-time PCR for hypothalamic and ChP samples. 
Table 4. Sequences of oligonucleotide primers used for real-time PCR in the hypothalamus and choroid plexus.

\begin{tabular}{|c|c|c|c|c|}
\hline & Gene & (Forward/Reverse) Sequence $5^{\prime} \rightarrow 3^{\prime}$ & $\begin{array}{l}\text { Amplicon } \\
\text { Size (bp) }\end{array}$ & $\begin{array}{l}\text { References/ } \\
\text { Sources }\end{array}$ \\
\hline \multirow{14}{*}{ Genes under study } & $I L 1 B$ & $\begin{array}{l}\text { F: CAGCCGTGCAGTCAGTAAAA } \\
\text { R: GAAGCTCATGCAGAACACCA }\end{array}$ & 137 & {$[24,68]$} \\
\hline & IL1R1 & $\begin{array}{l}\text { F: GGGAAGGGTCCACCTGTAAC } \\
\text { R: ACAATGCTTTCCCCAACGTA }\end{array}$ & 124 & {$[24,68]$} \\
\hline & IL1R2 & $\begin{array}{l}\text { F: CGCCAGGCATACTCAGAAA } \\
\text { R: GAGAACGTGGCAGCTTCTTT }\end{array}$ & 162 & {$[24,68]$} \\
\hline & & F: GTTCAATCAGGCGATTTGCT & & \\
\hline & IL6 & R: CCTGCGATCTTTTCCTTCAG & 165 & {$[24,68]$} \\
\hline & & F: TCAGCGACTCCGGAAACTAT & & \\
\hline & IL6R & R: CCGAGGACTCCACTCACAAT & 149 & {$[24,68]$} \\
\hline & II $6 S T$ & F: GGCTTGCCTCCTGAAAAACC & 139 & {$[2468]$} \\
\hline & IL6S1 & R: ACTTCTCTGTTGCCCACTCAG & 139 & {$[24,68]$} \\
\hline & $T N F$ & F: CAAATAACAAGCCGGTAGCC & 153 & {$[24,68]$} \\
\hline & INF & R: AGATGAGGTAAAGCCCGTCA & 153 & {$[24,08]$} \\
\hline & TNERSE1A & F: AGGTGCCGGGATGAAATGTT & 137 & {$[2468]$} \\
\hline & INFКОГ & R: CAGAGGCTGCAGTTCAGACA & 137 & {$[24,08]$} \\
\hline & TNFSFR $2 A$ & $\begin{array}{l}\text { F: ACСТTCTTCСТССТСССАAА } \\
\text { R: AGAAGCAGACCCAATGCTGT }\end{array}$ & 122 & {$[24,68]$} \\
\hline \multirow{7}{*}{$\begin{array}{l}\text { Reference } \\
\text { genes }\end{array}$} & GAPDH & $\begin{array}{l}\text { F: AGAAGGCTGGGGCTCACT } \\
\text { R: GGCATTGCTGACAATCTTGA }\end{array}$ & 134 & [68] hypothalamus \\
\hline & GAPDH & $\begin{array}{l}\text { F: TGACCCCTTCATTGACCTTC } \\
\text { R: GATCTCGCTCCTGGAAGATG }\end{array}$ & 143 & [72] ChP \\
\hline & & F: CTTCCTTCCTGGGCATGG & & \\
\hline & $A C T B$ & R: GGGCAGTGATCTCTTTCTGC & 168 & [68] hypothalamus \\
\hline & $A C T B$ & $\begin{array}{l}\text { F: GCCAACCGTGAGAAGATGAC } \\
\text { R: TCCATCACGATGCCAGTG }\end{array}$ & 122 & [72] ChP \\
\hline & & F: CTGGGGACCTACGGGATATT & & \\
\hline & $H D A C 1$ & R: GACATGACCGGCTTGAAAAT & 115 & {$[24,68]$} \\
\hline
\end{tabular}

IL1B-interleukin 1-beta; IL1R1—interleukin 1 receptor, type I; IL1R2—interleukin 1 receptor, type II; IL6-interleukin 6; IL6R-interleukin 6 receptor; IL6ST—glycoprotein 130; TNF-tumor necrosis factor; TNFRSF1A—tumor necrosis factor receptor superfamily member 1A; TNFRSF1B — tumor necrosis factor receptor superfamily member 1B; GAPDH—glyceraldehyde-3-phosphate dehydrogenase; $A C T B$ - betaactin; $H D A C 1$ - histone deacetylase $1 ; \mathrm{ChP}$-choroid plexus.

\subsection{Statistical Analysis}

All data are presented as the mean \pm SEM. Gene expression data were normalized to the average relative level of this mRNA expression in the control sheep, which was set to 1.0. The statistical analysis was performed using a STATISTICA 10 software (Stat Soft. Inc., Tulsa, OK, USA) for hypothalamic samples and a Graph Pad PRISM 8 (Graph Pad Software, San Diego, CA, USA) for ChP samples. The analyses were performed on raw data after verification of normality assumptions (Shapiro-Wilk's test). Before analysis, data that failed the normality test were subjected to logarithmic transformation. The results of gene and protein expression were analyzed using one-way analyses of variances (ANOVA) and followed by a post-hoc Fisher's least significance test comparing groups with each other. The results are presented as the mean \pm SEM; statistical significance was set at $p<0.05$.

\section{Conclusions}

Our study on the sheep model reveals that CAF may exert anti-inflammatory effects in the hypothalamus, among others by inhibiting the synthesis of pro-inflammatory cytokines such as IL-1 $\beta$ and TNF $\alpha$. It was also determined that CAF may influence the gene expression of TNF $\alpha$ and some cytokines receptors in the ChP by which it may influence the inflammatory signal generated by the $\mathrm{ChP}$. Due to the important role of the hypothalamus in the control of reproduction, a better understanding of the potential of CAF to suppress the neuroinflammatory processes may be important. However, further in-depth research 
is needed to better define and understand the mechanism by which CAF influences the synthesis of inflammatory mediators in the CNS.

Supplementary Materials: The following are available online at https:/ /www.mdpi.com/article/10 $.3390 /$ ijms222413237/s1.

Author Contributions: Conceptualization, A.P.H. and J.S.; methodology, A.S. and A.P.H.; software, A.S., M.W. and A.P.H.; validation, A.S. and M.W.; formal analysis, A.S. and A.P.H.; investigation, A.S., M.W., H.A., A.K. and W.W.; resources, A.P.H.; data curation, A.S. and A.P.H.; writing-original draft preparation, A.S., J.S. and A.P.H.; writing-review and editing, J.S., A.P.H. and D.T.-Z.; visualization, A.S.; supervision, A.P.H.; project administration, M.W. and A.P.H.; funding acquisition, A.P.H. All authors have read and agreed to the published version of the manuscript.

Funding: This work was supported by the funds granted by National Science Centre, Poland based on the decision no DEC-2017/25/B/NZ9/00225. A.S. and J.S. were supported by the Institute of Animal Reproduction and Food Research PAS statutory research funds.

Institutional Review Board Statement: The study was conducted according to the guidelines of the Declaration of Helsinki, and approved by the II Local Ethics Committee of Warsaw University of Life Sciences-SGGW (authorization no. WAW2/023/2018; 2 February 2018).

Data Availability Statement: The data presented in this study are available on request from the corresponding authors.

Conflicts of Interest: The authors declare no conflict of interest.

\section{References}

1. Kluger, M.J. Fever: Role of pyrogens and cryogens. Physiol. Rev. 1991, 71, 93-127. [CrossRef] [PubMed]

2. Battaglia, D.F.; Bowen, J.M.; Krasa, H.B.; Thrun, L.A.; Viguie, C.; Karsch, F.J. Endotoxin inhibits the reproductive neuroendocrine axis while stimulating adrenal steroids: A simultaneous view from hypophyseal portal and peripheral blood. Endocrinology 1997, 138, 4273-4281. [CrossRef]

3. Lawrence, C.B.; Rothwell, N.J. Anorexic but not pyrogenic actions of interleukin-1 are modulated by central melanocortin-3/4 receptors in the rat. J. Neuroendocrinol. 2001, 13, 490-495. [CrossRef]

4. Palomba, M.; Bentivoglio, M. Chronic inflammation affects the photic response of the suprachiasmatic nucleus. J. Neuroimmunol. 2008, 193, 24-27. [CrossRef] [PubMed]

5. Suzuki, C.; Yoshioka, K.; Iwamura, S.; Hirosa, H. Endotoxin induces delayed ovulation following endocrine aberration during the proestrous phase In Holstein heifers. Dom. Anim. Endocrinol. 2001, 20, 267-278. [CrossRef]

6. Daniel, J.A.; Abrams, M.S.; De Souza, L.; Wagner, C.G.; Whitlock, B.K.; Sartin, J.L. Endotoxin inhibition of luteinizing hormone in sheep. Domest. Anim. Endocrinol. 2003, 25, 13-19. [CrossRef]

7. Jana, B.; Kucharski, J.; Zięcik, A. Effect of intrauterine infusion of Escherichia coli on hormonal patterns in gilts during the estrous cycle. Reprod. Nutr. Dev. 2004, 44, 37-48. [CrossRef] [PubMed]

8. Refojo, D.; Arias, P.; Moguilevsky, J.A.; Felder, C. Effect of bacterial endotoxin on in vivo pulstile gonadotropin secretion in adult male rats. Neuroendocrinology 1998, 67, 275-281. [CrossRef]

9. Xiao, E.; Xia-Zhang, L.; Barth, A.; Zhu, J.; Ferin, M. Stress and the menstrual cycle: Relevance of cycle quality in the short- and long-term response to a 5-day endotoxin challenge during the follicular phase in the rhesus monkey. J. Clin. Endocrinol. Metab. 1998, 83, 2454-2460. [CrossRef]

10. Rapone, B.; Ferrara, E.; Montemurro, N.; Ilaria Converti, I.; Loverro, M.; Loverro, M.T.; Gnoni, A.; Scacco, S.; Siculella, L.; Corsalini, M.; et al. Oral Microbiome and Preterm Birth: Correlation or Coincidence? A Narrative Review. Open Access Maced J. Med. Sci. 2020, 8, 123-132. [CrossRef]

11. Tomaszewska-Zaremba, D.; Herman, A. The role of immunological system in the regulation of gonadoliberin and gonadotropin secretion. Reprod. Biol. 2009, 9, 11-23. [CrossRef]

12. Creasey, A.A.; Stevens, P.; Kenney, J.; Allison, A.C.; Warren, K.; Catlett, R.; Hinshaw, L.; Taylor, F.B., Jr. Endotoxin and cytokine profile in plasma of baboons challenged with lethal and sublethal Escherichia coli. Circ. Shock. 1991, 33, 84-91. [PubMed]

13. Watanobe, H.; Hayakawa, Y. Hypothalamic interleukin- $1 \beta$ and tumor necrosis factor- $\alpha$, but not interleukin-6, mediate the endotoxin-induced suppression of the reproductive axis in rats. Endocrinology 2003, 144, 4868-4875. [CrossRef] [PubMed]

14. Erickson, M.A.; Banks, W.A. Cytokine and chemokine responses in serum and brain after single and repeated injections of lipopolysaccharide: Multiplex quantification with path analysis. Brain Behav. Immun. 2011, 25, 1637-1648. [CrossRef]

15. Skipor, J.; Kowalewska, M.; Szczepkowska, A.; Majewska, A.; Misztal, T.; Jalynski, M.; Herman, A.P.; Zabek, K. Plasma and cerebrospinal fluid interleukin-1 $\beta$ during lipopolysaccharide-induced systemic inflammation in ewes implanted or not with slow-release melatonin. J. Anim. Sci. Biotechnol. 2017, 8, 76. [CrossRef] 
16. Rivest, S.; Lee, S.; Attardi, B.; Rivier, C. The chronic intracerebroventricular infusion of interleukin-1b alters the activity of the hypothalamic-pituitary-gonadal axis of cycling rats. I. Effect on LHRH and gonadotropin biosynthesis and secretion. Endocrinology 1993, 133, 2424-2430. [CrossRef]

17. Herman, A.P.; Tomaszewska-Zaremba, D. Effect of endotoxin on the expression of GnRH and GnRHR genes in the hypothalamus and anterior pituitary gland of anestrous ewes. Anim. Reprod. Sci. 2010, 120, 105-111. [CrossRef]

18. Herman, A.P.; Misztal, T.; Romanowicz, K.; Tomaszewska-Zaremba, D. Central injection of exogenous IL-1 $\beta$ in the control activities of hypothalamic-pituitary-gonadal axis in anestrous ewes. Reprod. Domest. Anim. 2012, 47, 44-52. [CrossRef]

19. Herman, A.P.; Skipor, J.; Krawczyńska, A.; Bochenek, J.; Wojtulewicz, K.; Pawlina, B.; Antushevich, H.; Herman, A.; TomaszewskaZaremba, D. Effect of central injection of neostigmine on the bacterial endotoxin induced suppression of GnRH/LH secretion in ewes during the follicular phase of the estrous cycle. Int. J. Mol. Sci. 2019, 20, 4598. [CrossRef] [PubMed]

20. Banks, W.A.; Kastin, A.J.; Broadwell, R.D. Passage of cytokines across the blood-brain barier. Neuroimmunomodulation 1995, 2, 241-248. [CrossRef]

21. Pan, W.; Stone, K.P.; Hsuchou, H.; Manda, V.K.; Zhang, Y.; Kastin, A.J. Cytokine signaling modulates blood-brain barrier function. Curr. Pharm. Des. 2011, 17, 3729-3740. [CrossRef]

22. Vitkovic, L.; Konsman, J.P.; Bockaert, J.; Dantzer, R.; Homburger, V.; Jacque, C. Cytokine signals propagate through the brain. Mol. Psychiatry 2000, 5, 604-615. [CrossRef] [PubMed]

23. Kovac, A.; Erickson, M.A.; Banks, W.A. Brain microvascular pericytes are immunoactive in culture: Cytokine, chemokine, nitric oxide, and LRP-1 expression in response to lipopolysaccharide. J. Neuroinflamm. 2011, 8, 139. [CrossRef] [PubMed]

24. Kowalewska, M.; Herman, A.P.; Szczepkowska, A.; Skipor, J. The effect of melatonin from slow-release implants on basic and TLR-4-mediated gene expression of inflammatory cytokines and their receptors in the choroid plexus in ewes. Res. Vet. Sci. 2017, 113, 50-55. [CrossRef]

25. Ghersi-Egea, J.F.; Strazielle, N.; Catala, M.; Silva-Vargas, V.; Doetsch, F.; Engelhardt, B. Molecular anatomy and functions of the choroidal blood-cerebrospinal fuid barrier in health and disease. Acta Neuropathol. 2018, 135, 337-361. [CrossRef] [PubMed]

26. Meeker, R.B.; Williams, K.; Killebrew, D.A.; Hudson, L.C. Cell trafficking through the choroid plexus. Cell Adhes. Migr. 2012, 6, 390-396. [CrossRef] [PubMed]

27. Chen, G.Q.; Chen, Y.Y.; Wang, X.S.; Wu, S.Z.; Yang, H.M.; Xu, H.Q.; He, J.C.; Wang, X.T.; Chen, J.F.; Zheng, R.Y. Chronic caffeine treatment attenuates experimental autoimmune encephalomyelitis induced by guinea pig spinal cord homogenates in Wistar rats. Brain Res. 2010, 1309, 116-125. [CrossRef]

28. Cechella, J.L.; Leite, M.R.; Dobrachinski, F.; da Rocha, J.T.; Carvalho, N.R.; Duarte, M.M.; Soares, F.A.; Bresciani, G.; Royes, L.F.; Zeni, G. Moderate swimming exercise and caffeine supplementation reduce the levels of inflammatory cytokines without causing oxidative stress in tissues of middle-aged rats. Amino Acids 2014, 46, 1187-1195. [CrossRef] [PubMed]

29. Iris, M.; Tsoua, P.S.; Sawalha, A.H. Caffeine inhibits STAT1 signaling and downregulates inflammatory pathways involved in autoimmunity. Clinical. Immunol. 2018, 192, 68-77. [CrossRef]

30. Chavez-Valdez, R.; Wills-Karp, M.; Ahlawat, R.; Cristofalo, E.A.; Nathan, A.; Gauda, E.B. Caffeine modulates TNF-alpha production by cord blood monocytes: The role of adenosine receptors. Pediatr. Res. 2009, 65, 203-208. [CrossRef]

31. Lv, X.; Chen, Z.; Li, J.; Zhang, L.; Liu, H.; Huang, C.; Zhu, P. Caffeine protects against alcoholic liver injury by attenuating inflammatory response and oxidative stress. Inflamm. Res. 2010, 59, 635-645. [CrossRef]

32. Fredholm, B.B.; IJzerman, A.P.; Jacobson, K.A.; Klotz, K.N.; Linden, J. International Union of Pharmacology. XXV. Nomenclature and classification of adenosine receptors. Pharmacol. Rev. 2001, 53, 527-552.

33. Chavez-Valdez, R.; Ahlawat, R.; Wills-Karp, M.; Gauda, E.B. Mechanisms of modulation of cytokine release by human cord blood monocytes exposed to high concentrations of caffeine. Pediatr. Res. 2016, 80, 101-109. [CrossRef] [PubMed]

34. Sheth, S.; Brito, R.; Mukherjea, D.; Rybak, L.P.; Ramkumar, V. Adenosine receptors: Expression, function and regulation. Int. J. Mol. Sci. 2014, 15, 2024-2052. [CrossRef]

35. Kalaria, R.N.; Harik, S.I. Adenosine receptors of cerebral microvessels and choroid plexus. J. Cereb. Blood Flow Metab. 1986, 6, 463-470. [CrossRef]

36. Mills, J.H.; Thompson, L.F.; Mueller, C.; Waickman, A.T.; Jalkanen, S.; Niemela, J.; Airas, L.; Bynoe, M.S. CD73 is required for efficient entry of lymphocytes into the central nervous system during experimental autoimmune encephalomyelitis. Proc. Natl. Acad. Sci. USA 2008, 105, 9325-9330. [CrossRef] [PubMed]

37. Eltzschig, H.K.; Sitkovsky, M.V.; Robson, S.C. Purinergic signaling during inflammation. N. Engl. J. Med. 2012, $367,2322-2333$. [CrossRef]

38. Available online: https://maayanlab.cloud/Harmonizome/gene_set/choroid+plexus+of+the+lateral+ventricle/Allen+Brain+ Atlas+Adult+Human+Brain+Tissue+Gene+Expression+Profiles (accessed on 12 May 2021).

39. Popov, D.; Pavlov, G. Sepsis models in experimental animals. Trakia J.Ournal Sci. 2013, 1, 13-23.

40. Piccione, G.; Giannetto, C.; Casella, S.; Caola, G. Circadian activity rhythm in sheep and goats housed in stable conditions. Folia Biol. 2008, 56, 133-137. [CrossRef]

41. Skipor, J.; Szczepkowska, A.; Kowalewska, M.; Domżalska, M.; Herman, A.P.; Krawczyńska, A. Photoperiod alters the choroid plexus response to LPS-induced acute inflammation in ewes. Ann. Anim. Sci. 2021, 21, 497-512. [CrossRef] 
42. Mallik, S.B.; Mudgal, J.; Susan Hall, S.; Kinra, M.; Grant, G.D.; Nampoothiri, M.; Anoopkumar-Dukie, S.; Arora, D. Remedial effects of caffeine against depressive-like behaviour in mice by modulation of neuroinflammation and BDNF. Nutr. Neurosci. 2021, 5, 1-9. [CrossRef]

43. Banks, W.A.; Robinson, S.M. Minimal penetration of lipopolysaccharide across the murine blood-brain barrier. Brain Behav. Immun. 2010, 24, 102-109. [CrossRef] [PubMed]

44. Nagyőszi, P.; Wilhelm, I.; Farkas, A.E.; Fazakas, C.; Dung, N.T.; Hasko, J.; Krizbai, I.A. Expression and regulation of toll-like receptors in cerebral endothelial cells. Neurochem. Int. 2010, 57, 556-564. [CrossRef] [PubMed]

45. Skipor, J.; Szczepkowska, A.; Kowalewska, M.; Herman, A.P.; Lisiewski, P. Profile of toll-like receptor mRNA expression in the choroid plexus in adult ewes. Acta Vet. Hung. 2015, 63, 69-78. [CrossRef] [PubMed]

46. Lopez-Castejon, G.; Brough, D. Understanding the mechanism of IL-1ß secretion. Cytokine Growth Factor Rev. 2011, 22, 189-195. [CrossRef]

47. Halle, A.; Hornung, V.; Petzold, G.C.; Stewart, C.R.; Monks, B.G.; Reinheckel, T.; Fitzgerald, K.A.; Latz, E.; Moore, K.J.; Golenbock, D.T. The NALP3 inflammasome is involved in the innate immune response to amyloid-beta. Nat. Immunol. 2008, 9, 857-865. [CrossRef]

48. Jha, S.; Srivastava, S.Y.; Brickey, W.J.; Iocca, H.; Toews, A.; Morrison, J.P.; Chen, V.S.; Gris, D.; Matsushima, G.K.; Ting, J.P. The inflammasome sensor, NLRP3, regulates CNS inflammation and demyelination via caspase-1 and interleukin-18. J. Neurosci. 2010, 30, 15811-15820. [CrossRef] [PubMed]

49. Nagyőszi, P.; Nyúl-Tóth, Á.; Fazakas, C.; Wilhelm, I.; Kozma, M.; Molnár, J.; Haskó, J.; Krizbai, I.A. Regulation of NOD-like receptors and inflammasome activation in cerebral endothelial cells. J. Neurochem. 2015, 135, 551-564. [CrossRef] [PubMed]

50. Wang, H.Q.; Song, K.Y.; Feng, J.Z.; Huang, S.Y.; Guo, X.M.; Zhang, L.; Zhang, G.; Huo, Y.C.; Zhang, R.R.; Ma, Y.; et al. Caffeine Inhibits Activation of the NLRP3 Inflammasome via Autophagy to Attenuate Microglia-Mediated Neuroinflammation in Experimental Autoimmune Encephalomyelitis. J. Mol. Neurosci. 2021. [CrossRef] [PubMed]

51. Shimada, A.; Hasegawa-Ishii, S. Increased cytokine expression in the choroid plexus stroma and epithelium in response to endotoxin-induced systemic inflammation in mice. Toxicol. Rep. 2021, 8, 520-528. [CrossRef] [PubMed]

52. Atri, C.; Guerfali, F.Z.; Laouini, D. Role of Human Macrophage Polarization in Inflammation during Infectious Diseases. Int. J. Mol. Sci. 2018, 19, 1801. [CrossRef] [PubMed]

53. Ivan, D.C.; Walthert, S.; Locatelli, G. Central Nervous System Barriers Impact Distribution and Expression of iNOS and Arginase-1 in Infiltrating Macrophages During Neuroinflammation. Front. Immunol. 2021, 12, 666961. [CrossRef]

54. Kovács, E.G.; Alatshan, A.; Budai, M.M.; Czimmerer, Z.; Bíró, E.; Benkő, S. Caffeine Has Different Immunomodulatory Effect on the Cytokine Expression and NLRP3 Inflammasome Function in Various Human Macrophage Subpopulations. Nutrients 2021, 13, 2409. [CrossRef]

55. Skinner, R.A.; Gibson, R.M.; Rothwell, N.J.; Pinteaux, E.; Penny, J.I. Transport of interleukin-1 across cerebromicrovascular endothelial cells. Br. J. Pharmacol. 2009, 156, 1115-1123. [CrossRef] [PubMed]

56. Carman, A.J.; Mills, J.H.; Krenz, A.; Kim, D.G.; Bynoe, M.S. Adenosine receptor signaling modulates permeability of the blood-brain barrier. J. Neurosci. 2011, 31, 13272-13280. [CrossRef] [PubMed]

57. Bynoe, M.S.; Viret, C.; Yan, A.; Kim, D.G. Adenosine receptor signaling: A key to opening the blood-brain door. Fluids Barriers CNS 2015, 12, 20. [CrossRef] [PubMed]

58. Horrigan, L.A.; Kelly, J.P.; Connor, T.J. Caffeine suppresses TNF-alpha production via activation of the cyclic AMP/protein kinase A pathway. Int. Immunopharmacol. 2004, 4, 1409-1417. [CrossRef]

59. Idriss, H.T.; Naismith, J.H. TNF alpha and the TNF receptor superfamily: Structure-function relationship(s). Microsc. Res. Tech. 2000, 50, 184-195. [CrossRef]

60. Hwang, J.H.; Kim, K.J.; Ryu, S.J.; Lee, B.Y. Caffeine prevents LPS-induced inflammatory responses in RAW264.7 cells and zebrafish. Chem. Biol. Interact. 2016, 248, 1-7. [CrossRef] [PubMed]

61. Tauler, P.; Martínez, S.; Moreno, C.; Monjo, M.; Martínez, P.; Aguiló, A. Effects of caffeine on the inflammatory response induced by a 15-km run competition. Med. Sci. Sports Exerc. 2013, 45, 1269-1276. [CrossRef]

62. Rodas, L.; Martinez, S.; Aguilo, A.; Tauler, P. Caffeine supplementation induces higher IL-6 and IL-10 plasma levels in response to a treadmill exercise test. J. Int. Soc. Sports Nutr. 2020, 17, 47. [CrossRef]

63. Fang, C.; Cai, X.; Hayashi, S.; Hao, S.; Sakiyama, H.; Wang, X.; Yang, Q.; Akira, S.; Nishiguchi, S.; Fujiwara, N.; et al. Caffeinestimulated muscle IL-6 mediates alleviation of non-alcoholic fatty liver disease. Biochim. Biophys. Acta Mol. Cell Biol. Lipids 2019, 1864, 271-280. [CrossRef]

64. Bustamante, A.; Sobrino, T.; Giralt, D.; García-Berrocoso, T.; Llombart, V.; Ugarriza, I.; Espadaler, M.; Rodríguez, N.; Sudlow, C.; Castellanos, M.; et al. Prognostic value of blood interleukin-6 in the prediction of functional outcome after stroke: A systematic review and meta-analysis. J. Neuroimmunol. 2014, 274, 215-224. [CrossRef]

65. Pasquini, S.; Contri, C.; Borea, P.A.; Vincenzi, F.; Varani, K. Adenosine and Inflammation: Here, There and Everywhere. Int. J. Mol. Sci. 2021, 22, 7685. [CrossRef]

66. Rossetto, I.M.U.; Cagnon, V.H.A.; Kido, L.A.; Lizarte Neto, F.S.; Tirapelli, L.F.; Tirapelli, D.P.D.C.; de Almeida Chuffa, L.G.; Martinez, F.E.; Martinez, M. Caffeine consumption attenuates ethanol-induced inflammation through the regulation of adenosinergic receptors in the UChB rats cerebellum. Toxicol. Res. 2021, 10, 835-849. [CrossRef]

67. Rosas-Ballina, M.; Tracey, K.J. Cholinergic control of inflammation. J. Intern. Med. 2009, 265, 663-679. [CrossRef] 
68. Herman, A.P.; Tomaszewska-Zaremba, D.; Kowalewska, M.; Szczepkowska, A.; Oleszkiewicz, M.; Krawczyńska, A.; Wójcik, M.; Antushevich, H.; Skipor, J. Neostigmine Attenuates Proinflammatory Cytokine Expression in Preoptic Area but Not Choroid Plexus during Lipopolysaccharide-Induced Systemic Inflammation. Mediat. Inflamm. 2018, 2018, 9150207. [CrossRef]

69. Pohanka, M.; Dobes, P. Caffeine inhibits acetylcholinesterase, but not butyrylcholinesterase. Int. J. Mol. Sci. 2013, 14, 9873-9882. [CrossRef] [PubMed]

70. Pollard, I.; Williamson, S.; Downing, J.; Scaramuzzi, R. Pharmacokinetics of caffeine in the oestrogen-implanted ovariectomized ewe. J. Vet. Pharmacol. Ther. 1996, 19, 113-117. [CrossRef] [PubMed]

71. Kokot, F. Metody Radioimmunologiczne i Radiokompetycyjne Stosowane w Klinice; Państwowy Zakład Wydawnictw Lekarskich: Warsaw, Poland, 1985.

72. Szczepkowska, A.; Kowalewska, M.; Krawczyńska, A.; Herman, A.P.; Skipor, J. Photoperiod Affects Leptin Action on the Choroid Plexus in Ewes Challenged with Lipopolysaccharide-Study on the mRNA Level. Int. J. Mol. Sci. 2020, 21, 7647. [CrossRef] [PubMed]

73. Rasmussen, R. Quantification on the LightCycler. In Rapid Cycle Real-Time PCR Methods and Applications; Meuer, S., Wittwer, C., Nakagawara, K., Eds.; Springer: Berlin, Germany, 2001; pp. 21-34.

74. Zhao, S.; Fernald, R.D. Comprehensive algorithm for quantitative real-time polymerase chain reaction. J. Comput. Biol. 2005, 12, 1047-1064. [CrossRef] 